\title{
ANALISIS KANDUNGAN MPN DAN ALT TOTAL PADA FISH NUGGET BERBAHAN DASAR LIMBAH IKAN
}

\author{
Muhammad Rijal \\ Dosen FITK IAIN Ambon \\ E-mail: rijal_rijal82@yahoo.co.id
}

\begin{abstract}
Abstrak: Pengembangan sektor kelautan dan perikanan dapat diandalkan untuk pertumbuhan ekonomi di masa depan jika permasalahan yang ada dapat diatasi secara bertahap. Salah satu masalah yang muncul dengan meningkatnya produksi perikanan adalah dihasilkannya limbah perikanan yang dapat mencemari lingkungan. Fish nugget berbaha limbah ikan merupakan salah satu solusi yang tepat untuk mengatasi permasalahan tersebut. Hasil penelitian menunjukkan bahwakandungan total koliform, angka lempeng total bakteri, dan angka lempeng total jamur adalah $0 \mathrm{kol} / \mathrm{ml}$ sehingga produk olahan dari limbah ikanm berupa fish nugget aman untuk dikonsumsi
\end{abstract}

Kata Kunci: Alt, Fish Nugget, Limbah Ikan

\section{ANALYSIS MPN CONTENT AND ALT TOTAL IN FISH NUGGETS URANIUM-BASED WASTE FISH}

\begin{abstract}
Sector development maritime affairs and fisheries reliable for economic growth in a future if problems could be reduced gradually. One of the problems that come through increasing production fisheries waste is it a fishing can pollute environment. Fish nuggets made waste fish is one of the best solution to overcome the problems. The research results show the content total coliform, the plates total bacteria, and the plates total fungi is $0 \mathrm{col} / \mathrm{ml}$ so that the product processed of sewage fish of fish nuggets safe to eat
\end{abstract}

\section{Keywords: Alt, Fish Nugget, Fish Waste}

Limbah merupakan masalah di dalam usaha suatu industri termasuk industri perikanan yang menghasilkan limbah pada proses penangkapan ikan, penanganan, pengangkutan, distribusi dan pemasaran. Limbah perikanan dapat dapat berupa ikan yang terbuang, tercecer, dan sisa olahan yang menghasilkan cairan dan pemotongan, pencucian dan pengolahan produk. Dampak limbah industri pengolahan ikan terhadap kesehatan lingkungan dapat dirasakan dengan bau limbah ikan yang menyengat sehingga mencemari udara, dapat dihinggapi lalat yang dapat menimbulkan penyakit dan berbagai 
dampak negatif lainnya. Industri pengolahan ikan harus memiliki metode dalam pengolahan limbah olahan ikan sehingga limbah olahan ikan tidak hanya dibuang begitu saja ditempat pembuang sampah.Bila industri pengolahan limbah tidak memperhatikan hal ini maka dapat menjadi tempat pertumbuhan bakteri dan virus yang dapat menyebabkan penyakit.

Penanganan limbah olahan ikan harus menjadi perhatian besar bagi kita semua, apalagi di industri pengolahan ikan tradisional yang tidak memperhatikan limbah ikannya.Dinas kesehatan setempat harus memberikan gambaran kepada pengusaha industri pengolahan ikan tentang bahaya limbah industri. Limbah ikan tuna merupakan hasil sampingan dari pengolahan industri perikanan dan diharapkan dapat dimanfaatkan sebagai bahan pakan alternatif untuk makanan ternak atau dapat diolah menjadi aneka produk makanan.Limbah ikan yang terdiri atas kepala, isi perut, kulit, dan tulang jumlahnya mencapai 271000 ton per tahun. Limbah tersebut mudah rusak, sehingga perlu pengolahan.Pengolahan ditujukan untuk menghasilkan produk berprotein tinggi yang tidak mengalami kerusakan berarti selama penyimpanan beberapa bulan bahkan bertahun-tahun.Untuk meningkatkan nilai guna limbah tersebut, perlu diolah supaya lebih bermanfaat untuk bahan makanan dengan kandungan gizi dan nilai ekonomi yang cukup tinggi (Murniyati dan Sunarman, 2000).

Proses pengolahan ikan dengan hanya memanfaatkan daging mengakibatkan banyaknya limbah ikan yang dihasilkan dan limbah tersebut tidak semuanya dikelolah dengan baik oleh masyarakat setempat. Limbah ikan yang meliputi kepala, tulang, dan jeroan memiliki kandungan gizi yang cukup tinggi, seperti jeroan dan kepala ikan masih banyak mengandung protein dan omega 6 serta omega 9, sedangkan bagian tulang banyak mengandung calcium yang sangat baik diolah menjadi pakan ternak. Limbah ikan berupa kepala dan jeroan dapat diolah menjadi aneka produk makanan yang bernilai ekonomi dan gizi yang tinggi. Nugget, bakso ikan, otak-otak, dan kerupuk merupakan produk makanan yang dapat dibuat dengan menggunakan bahan dasar dari daging kepala dan jeroan ikan, sehingga kandungan gizi dari limbah ikan tersebut tidak terbuang percuma. Dalam pengolahan limbah ikan berupa kepala dan jeroan dilakukan inovasi berbasis biologi terapan yaitu memadukan bahan alami yang dapat meningkatkan nilai gizi dari produk olahan. Produk olahan dari limbah ikan perlu melalui proses pengujian secara mikrobiologi karena bahan organik seperti sisa daging ikan merupakan media pertumbuhan yang baik bagi mikroba. Olehnya itu, untuk keamanan pangan, dilakukan pegujian kandungan MPN dan ALT total pada fish nugget yang terbuat dari limbah ikan

\section{METODE PENELITIAN}

Jenis penelitian ini adalah eksperimen laboratorium yang bertujuan untuk menganalisis kandungan angka lempeng total (ALT) bakteri dan jamur serta menganalisis kandungan MPN koliform total sebagai dasar pengujian keamanan pangan ditinjau dari 
segi mikrobiologi. Penelitian ini dilaksanakan selama 2 bulan yang terhitung mulai bulan juni-juli 2016 yang berlokasi di 3 tempat yaitu: pengambilan limbah ikan di Asilulu Maluku Tengah sedangkan pembuatan fish nugget, pengujian angka lempeng total bakteri dan jamur dilakukan di laboratorium MIPA IAIN Ambon. obyek yang teramati dalam penelitian ini adalah angka lempeng total bakteri dan jamur serta MPN total pada fish nugget sebagai syarat kelayakan konsumsi produk olahan ikan dengan membandingkan Standar Nasional Indonesia (SNI 01-2332.3-2006).

\section{Pengujian MPN Total}

Pengujian total koliform yaitu dengan cara membuat laktosa broot dan mengisi tiap tabung reaksi + durham dengan $9 \mathrm{ml}$ LB. jumlah tabung reaksi yang berisi LB adalah 9 tabung untuk tiap pengujian. Tiga tabung pertama adalah tabung $10^{-1}$, tiga tabung kedua adalah $10^{-2}$, dan tiga tabung ke tiga adalah tabung $10^{-3}$.Mengisi masing-masing tabung reaksi dengan sampel sesuai dengan pengencerannya dan diinkubasi pada suhu $30^{\circ} \mathrm{C}$ selama 1 x 24 jam. Mengamati parameter pengujian berupa gelembung gas pada tabung durham, endapan, atau perubahan warna. Jika salah satu indikator terdapat pada tabung pengujian maka tabung tersebut dikatakan positif (+), dan jika tidak ada perubahan maka tabung dikatakan negatif (-). Membandingkan hasil pembacaan visual dengan tabel MPN seri 9 dan menghitung jumlah koliform total berdasarkan hasil pengamatan.

\section{Pengujian Angka Lempeng Total (ALT) Bakteri dan Jamur}

Selain pengujian peningkatan kadar protein, dilakukan juga pengujian angka lempeng total bakteri dan jamur sebagai dasar keamanan pangan dengan pembanding SNI olahan ikan (SNI 01-2332.3-2006). $10 \mathrm{~g}$ fish nugget dimasukkan secara steril ke dalam $90 \mathrm{ml}$ aquadest lalu dihomogenkan. Dipipet sebanyak $1 \mathrm{ml}$ lalu dimasukkan ke dalam 9 $\mathrm{ml}$ aquadest (tabung 1), lalu memipet $1 \mathrm{ml}$ lagi pada tabung pertama dan memasukkan ke dalam tabung ke dua yang berisi $9 \mathrm{ml}$ aquadest steril. Dilakukan proses pengenceran sampai tabung ke tiga. Mempersiapkan NA dan PDA plate dan menyebar 3 pengenceran terakhir ke dalam cawan petri yang berisi NA atau PDA sebanyak $1 \mathrm{ml}$. Menyebar sampel dengan menggunakan batang penyebar dan menginkubasi selama 1 x 24 jam untuk bakteri dan 4 x 24 jam untuk jamur. Melakukan perhitungan koloni dengan menggunakan colony counter dan mencatat hasil pengamatan.

\section{HASIL DAN PEMBAHASAN}

\section{Analisis KandunganMPN Total Fish Nugget}

MPN total adalah salah satu metode perkiraan yang menuju suatu nilai kebenaran untuk mengetahui ataupun mendeteksi adanya mikroba pada sampel yang diuji. Keberadaan bakteri koliform pada suatu sampel dapat menjadi indikator adanya jenis bakteri lain yang bersifat patogen maupun non patogen. Pengujian koliform menggunakan media pengujian yang disebut laktosa brooth yaitu media yang bahan dasarnya dari laktosa. Bakteri koliform memiliki kemampuan dalam memfermentasi 
laktosa sehingga media yang terfermentasi akan mengalami perubahan warna, munculnya gas, dan endapan. Data tentang kandungan MPN total pada fish nugget disajikan pada Tabel 1 berikut

Tabel 1. Kandungan MPN Total pada Fish Nugget

\begin{tabular}{|c|c|c|c|c|c|}
\hline \multirow{2}{*}{ Perlakuan } & \multicolumn{3}{|c|}{ Ulangan (jml/ml) } & $\begin{array}{c}\text { Jumlah } \\
(\mathrm{jml} / \mathrm{ml})\end{array}$ & $\begin{array}{c}\text { Rerata } \\
(\mathrm{jml} / \mathrm{ml})\end{array}$ \\
\cline { 2 - 4 } & 1 & 2 & 3 & 0 & 0 \\
\hline $100 \%$ & 0 & 0 & 0 & 0 & 0 \\
\hline $80 \%$ & 0 & 0 & 0 & 0 & 0 \\
\hline $40 \%$ & 0 & 0 & 0 & 0 & 0 \\
\hline
\end{tabular}

Hasil pemeriksaan pada tabung yang berisi LB dan sampel uji menunjukkan tidak ditemukan adanya pertumbuhan bakteri koliform. Lama pengamatan adalah 1 x 24 jam sesuai dengan standar waktu pengamatan metode MPN, dan hasilnya semua tabung pada tiap-tiap pengenceran adalah negative (-) sehingga disimpulkan bahwa fish nugget yang dibuat dengan perlakuan ekstrak kulit nanas aman dari cemaran bakteri koliform.

\section{Analisis Angka Lempeng Total (ALT) Bakteri dan Jamur Fish Nugget}

Angka lempeng total merupakan salah satu metode perhitungan jumlah koloni mikroba baik bakteri maupun jamur yang terdapat pada sampel uji. Untuk mengetahui tingkat pencemaran bakteri, maka diginakan media Nutrient agar, sedangkan untuk mengetahui tingkat pencemaran jamur atau kapang digunakan media PDA. Metode ALT yang digunakan adalah metode sebar yaitu dengan menyebar secara aseptik $1 \mathrm{ml}$ sampel yang telah diencerkan di atas permukaan media padat kemudian disebarkan secara aseptic dengan menggunakan batang penyebar. Masa inkubasi untuk melihat prtumbuhan bakeri mupun jamur pada media $\mathrm{N}$ ataupun PDA adalah 3 x 24 jam. Data tentang kandungan bakteri dan jamur pada fish nugget disajikan pada Tabel 2 dan 3 sebagai berikut

Tabel 2. Kandungan Bakteri pada Fish Nugget

\begin{tabular}{|c|c|c|c|c|c|}
\hline \multirow{2}{*}{ Perlakuan } & \multicolumn{3}{|c|}{ Ulangan (kol/ml) } & $\begin{array}{c}\text { Jumlah } \\
(\mathrm{kol} / \mathrm{ml})\end{array}$ & $\begin{array}{c}\text { Rerata } \\
(\mathrm{kol} / \mathrm{ml})\end{array}$ \\
\cline { 2 - 4 } & 1 & 2 & 3 & 0 & 0 \\
\hline $100 \%$ & 0 & 0 & 0 & 0 & 0 \\
\hline $80 \%$ & 0 & 0 & 0 & 0 & 0 \\
\hline $60 \%$ & 0 & 0 & 0 & 0 & 0 \\
\hline $40 \%$ & 0 & 0 & 0 & & 0 \\
\hline
\end{tabular}

Tabel 3. Kandungan Jamur pada Fish Nugget

\begin{tabular}{|c|c|c|c|c|c|}
\hline \multirow{2}{*}{ Perlakuan } & \multicolumn{3}{|c|}{ Ulangan (kol/ml) } & \multirow{2}{*}{$\begin{array}{c}\text { Jumlah } \\
(\mathrm{kol} / \mathrm{ml})\end{array}$} & $\begin{array}{c}\text { Rerata } \\
(\mathrm{kol} / \mathrm{ml})\end{array}$ \\
\cline { 2 - 4 } & 1 & 2 & 3 & 0 & 0 \\
\hline $100 \%$ & 0 & 0 & 0 & 0 & 0 \\
\hline $80 \%$ & 0 & 0 & 0 & 0 & 0 \\
\hline $60 \%$ & 0 & 0 & 0 & 0 & 0 \\
\hline $40 \%$ & 0 & 0 & 0 & & 0 \\
\hline
\end{tabular}


Tabel 2 dan 3 menunjukkan bahwa angka lempeng total bakteri dan jamur pada sampel fish nugget yang diuji adalah $0 \mathrm{kol} / \mathrm{ml}$ untuk setiap perlakuan konsetrasi ekstrak kulit nanas. Waktu inkubasi yang digunakan oleh peneliti adalah 3 x 24 jam karena pengamatan 1 x 24 jam tidak menunjukkan pertumbuhan bakteri ataupun jamur pada media NA maupun PDA. Rentang waktu inkubasi yang diperpanjang selama 3 hari dimaksudkan untuk melihat adanya pertumbuhan bakteri atauun jamur pada media NA maupun PDA, tetapi setelah 3 x 24 jam hasil yang diperoleh tetap $0 \mathrm{kol} / \mathrm{ml}$, dengan kata lain bahwa fish nugget berbahan dasar limbah ikan dengan perlakuan konsentrasi eksrak kulit nanas aman untuk dikonsumsi

Bakteri coliform adalah golongan bakteri intestinal, yaitu hidup didalam saluran pencernaan manusia. Bakteri coliform adalah bakteri indikator keberadaan bakteri patogenik lain. Lebih tepatnya, bakteri coliform fekal adalah bakteri indikator adanya pencemaran bakteri patogen. Penentuan coliform fekal menjadi indikator pencemaran dikarenakan jumlah koloninya pasti berkorelasi positif dengan keberadaan bakteri patogen. Selain itu, mendeteksi coliform jauh lebih murah, cepat, dan sederhana daripada mendeteksi bakteri patogenik lain. Contoh bakteri coliform adalah, Escherichia coli dan Enterobacter aerogenes. Jadi, coliform adalah indikator kualitas pengujian suatu sampel makanan ataupun minuman. Makin sedikit kandungan coliform, artinya, kualitas produk semakin baik.E. coli jika masuk ke dalam saluran pencernaan dalam jumlah banyak dapat membahayakan kesehatan. Walaupun E. coli merupakan bagian dari mikroba normal saluran pencernaan, tapi saat ini telah terbukti bahwa galurgalur tertentu mampu menyebabkan gastroenteritis taraf sedang hingga parah pada manusia dan hewan. Sehingga, air yang akan digunakan untuk keperluan sehari-hari berbahaya dan dapat menimbulkan penyakit infeksius (Waluto, 2004). Bakteri kelompok koliform meliputi semua bakteri berbentuk batang, gram negatif, tidak membentuk spora dan dapat memfermentasi laktosa dengan memproduksi gas dan asam pada suhu $37{ }^{\circ} \mathrm{C}$ dalam waktu kurang dari 48 jam. Adapun bakteri E.coli selain memiliki karakteristik seperti bakteri koliform pada umumnya juga dapat menghasilkan senyawa indole di dalam air pepton yang mengandung asam amino triptofan, serta tidak dapat menggunakan natrium sitrat sebagai satu-satunya sumber karbon.

Hasil pengujian kandungan MPN koliform pada fish nugget, menunjukkan angka $0 \mathrm{jml} / \mathrm{ml}$, hal ini mengidikasikan bahwa fish nugget yang dibuat dari limbah ikan dengan perendaman ekstrak kulit nanas pada konsetrasi tertentu aman untuk dikonsumsi. Dugaan peneliti sebagai penyebab tidak ditemukannya kontaminasi total koliform pada fish nugget adalah proses pembuatan yang higienis dan dugaan bahwa perendaman ekstrak kulit nanas memberikan dampak mikroba tidak dapat tumbuh dengan baik pada fish nugget. Ekstrak kulit nanas mengandung $\mathrm{pH}$ rendah (asam) sehingga tidak disenangi oleh bakteri ataupun jamur, olehnya itu dalam penelitian ini tidak ditemukan bakteri koliform. 
Uji mikrobiologi suatu sediaan merupakan salah satu uji yang sangat penting untuk mengetahui kualitas suatu sediaan. Makanan, minuman, obat tradisional berasal dari alam yaitu dari hewan, tumbuhan, mineral ataupun sediaan galeniknya. Oleh karena didalam pengadaannya bahan-bahan tersebut mengalami proses pengangkutan dan penyimpanan dalam waktu yang cukup lama. Sehingga dalam proses tersebut dapat terjadi pertumbuhan mikroba di dalamnya. Untuk mengetahui bahwa bahan baku, bahan tambahan maupun sediaan jadi tidak mengalami perubahan sifat serta bebas dari kontaminan mikroba, maka diperlukan uji mikrobiologis, meliputi pengujian angka lempeng total (ALT), dan uji cemaran bakteri/kapang. Jika telah dilakukan uji-uji tersebut, dan tidak ditemukan bakteri dan kapang yang sesuai standar SNI, maka produk tersebut layak untuk dikonsumsi oleh masyarakat (Djidje, 2008).

Hasil pengujian kandungan ALT bakteri dan jamur pada fish nugget menunjukkan hasil $0 \mathrm{kol} / \mathrm{ml}$ yang berarti bahwa makanan yang dihasilkan aman untuk dikonsumsi karena tidak mengandung cemaran bakteri maupun jamur. Proses pembuatan yang higiens, pemilihan bahan dan alat yang higienis akan menghasilkan produk yang higienis. Selain itu penggunaan ekstrak kulit nanas dianggap memberikan konstribusi tidak tumbuhnya bakteri maupun jamur pada produk hasil olahan. Ekstrak kulit nanas mengandung $\mathrm{pH}$ rendah sehingga tidak disenangi oleh bakteri ataupun jamur.

Bahan makanan terdiri dari protein, karbohidrat, lemak, vitamin dan mineral.Bahkan makanan merupakan medium pertumbuhan yang baik bagi berbagai berbagai macam mikroorganisme. Mikroorganisme dapat membusukkan protein, memfermentasikan karbohidrat menjadikan lemak dan minyak berbau tengik. Berbagai macam uji mokrobiologis dapat dilakukan terhadap bahan pangan, meliputi uji kuantitatif mikroba untuk menentukan daya tahan suatu makanan, uji kualitatif bakteri patogen untuk menenetukan tingkat keamanan dan uji indikator untuk menentukan tingkat sanitasi makanan tersebut. Pengujian yang dilakukan terhadap tiap bahan pangan tidak sama tergantung berbagai faktor, seperti jenis dan komposisi bahan pangan, cara pengepakan dan penyimpanan serta komsumsinya, kelompok konsumen dan berbagai faktor lainnya (Djidje, 2008).

\section{KESIMPULAN}

1. Fish nugget berbahan dasar limbah ikan tidak mengandung cemaran koliform

2. Fish nugget berbahan dasar limbah ikan tidak mengandung cemaran bakteri dan jamur

\section{SARAN}

Perlu adanya pengujian kadar protein pada fish nugget yang diproduksi dengan menggunakan limbah ikan, sehingga dapat menjadi bahan informasi bagi masyarakat bahwa selain aman untuk dikonsumsi, fish nugget dari bahan limbah ikan mengandung protein yang cukup tinggi. 


\section{DAFTAR PUSTAKA}

Afrianto, E. dan Evi Liviawati. 1991. Pengawetan dan Pengolahan Ikan. Kanisius. Yogyakarta.

Anonim.2000. Petunjuk Praktikum Biokimia Untuk PSIK (B) Fakultas Kedokteran Universitas Gadjah Mada.Lab. Biokimia FK UGM. Yogyakarta

Burgess, G.H.O., C.L. Cutting, J.A. Lovern dan J.J. Waterman. 1965. Fish Handling and Processing. Her majesty's Stationary Office. Edinburg.

Fardiaz, S. 1993. Mikrobiologi Pangan I. PT. Gramedia Pustaka Utama. Jakarta

Guyton AC, Hall JE. 1996. Buku Ajar Fisiologi Kedokteran, Edisi IX, Penerjemah: Setiawan I, Tengadi LMAKA, Santoso A. EGC. Jakarta.

Junianto, Haetami dan Maulina.2006. Produksi Gelatin Dari Tulang Ikan Dan Pemanfaatannya Sebagai Bahan Dasar Pembuatan Cangkang Kapsul.http://pustaka.unpad.ac.id/wpcontent/produksi_gelatin_dari_tulang_ika $n . p d f$

Murniyati AS dan Sunarman. 2000. Pendinginan, Pembekuan dan Pengawetan Ikan. Kanisius. Yogyakarta.

Murray RK, Granner DK, Mayes PA, Rodwell VW. 2003. Biokimia Harper, Edisi XXV, Penerjemah Hartono Andry. EGC. Jakarta.

Nitibaskara, R. 1981. Laporan Studi Pengembangan Industri Kecil Pengolahan Ikan. Laporan Fakultas Perikanan IPB. Bogor.

Rijal, M. 2013. Biokimia Dasar. Hilyana Press. Bandung

Rijal, M. 2016. Prospek Limbah Ikan Di Maluku. Penerbit Deepublish. Sleman Yogyakarta.

Rombaut, R. 2005. Dairy Microbiology and Starter Cultures.Laboratory of Food Technology and Engineering. Gent University. Belgium

Rusmana, Deny dan Abun.2006. Evaluasi Nilai Kecernaan Limbah Ikan Tuna (Thunnusatlanticus) Produk Pengolahan Kimiawi Dan Biologi Serta Nilai Retensi Nitrogen Pada Ayam Broiler.http://pustaka.unpad.ac.id/wpcontent/uploads/2009/10.pdf.

Soekarto, S.T. 1990. Dasar-dasar Pengawasan dan Standarisasi Mutu Pangan.IPB Press. Bogor.

Stryer L. 1996. Biokimia. Edisi IV. Penerjemah: Sadikin dkk (Tim Penerjemah Bagian Biokimia FKUI). EGC. Jakarta.

Supardan. 1989. Metabolisme Protein. Lab. Biokimia Universitas Brawijaya. Malang.

Trilaksani, W, Salamah, E., Nabil, M. 2006. Pemanfaatan Limbah Tulang Ikan Tuna (Thunnus spp) sebagai Sumber Kalsium dengan Metode Hidrolisis Protein. BuletinTeknologi Hasil Perikanan Vol IX Nomor 2 Tahun 2006

Wong, DWS. 1989. Mechanism and Theory in Food Chemistry. Academic Press. Yogyakarta.

BIOLOGI SEL (VOL 5 NO 2 EDISI JUL-DES 2016 ISSN 2252-858X/E-ISSN 2541-1225) PAGE 150 
Zaitsev, V., I. Kizevetter, L. Lagunov, T. Makarova, L. Munder dan V. Podsevalow.1969. Fish Curing and Processing. Terjemahan A. De Marindol. M.R. Publisher. Moskow

Buckle, K. A., dkk. 2000. Ilmu Pangan. Diterjemahkan oleh Adiono dan Hari Purnomo. UI Press. Jakarta.

Djidje, M.N., Sartini. 2008. Analis Mikrobiologi Farmasi. Laboratorium Mikrobiologi Farmasi. Jurusan Farmasi F. MIPA. UNHAS. Makassar.

Djide, M. N. Sartini. 2005. Dasar-Dasar Mikrobiologi. Universitas Hasanuddin. Makassar.

Dwyana, Zaraswati. 2004. Analisis Mikrobiologi Bahan Pangan. Universitas Hasanuddin. Makassar.

Koes, Irianto. 2006. Mikrobiologi Jilid 2. Yasama Widya. Bandung.

Rijal, M., 2016. PENGOLAHAN DAN PENINGKATAN KADAR PROTEIN FISH NUGGET BERBAHAN DASAR LIMBAH IKAN DENGAN PEMBERIAN EKSTRAK KULIT NANAS. Biosel: Biology Science and Education, 5(1), pp. 84-92

Waluyo, Lud. 2004. Teknik Metode Dasar dalam Mikrobiologi. UMM Press. Malang 